\title{
PENGARUH AL-HIJAMAH TERHADAP PERUBAHAN KADAR LEUKOSIT
}

\author{
Oleh : \\ Ibrahim Edy Sapada \\ Dosen STIK Siti Khadijah Palembang Prodi S1 Farmasi \\ Email : ib_edys@yahoo.co.id
}

\begin{abstract}
Leucocyte fluctuations in large numbers in each individual occur under conditions of stress, high physiological activity, nutrition and age. The number of leucocytes that deviate from normal conditions has important clinical significance for the evaluation of the disease process. Al-Hijamah works by stimulating and activating the immune system, encephaline release, release of neurotransmitters, narrowing and dilation of blood vessels and the gates control theory on the central nervous system (which functions to reduce the sensation of pain). The aim of the study was to determine the effect of Al-Hijamah on changes in leucocyte levels This type of research is an experimental clinical trial without comparison (pre and post test without control group design).This research is done at the Ibnu Sina Clinic Cupping for 14 days. The Blood test was conducted at the center for Laboratory of Health (BBLK), South Sumatera region. Sample size of 30 people. The data which included a homogeneity test sample using the Shafiro wilk test, description analysis to know to mean value and standard deviation There was a significantly increase in the number of leucocyte. Al-Hijamah affected the increase leucocyte levels.
\end{abstract}

Keyword: Al-Hijamah, Leucocyte

\begin{abstract}
ABSTRAK
Fruktuasi leukosit dalam jumlah besar pada setiap individu terjadi pada kondisi stres, aktivitas fisiologi yang tinggi, gizi dan umur. Jumlah leukosit yang menyimpang dari keadaan normal mempunyai arti klinik penting untuk evaluasi proses penyakit. Al-Hijamah bekerja dengan cara merangsang dan mengaktifkan sistem kekebalan tubuh, pengeluaran enkefalin, pelepasan neurotransmitter, penyempitsn dan pelebaran pembuluh darah dan the gates control theory pada system saraf pusat (yang berfungsi mengurangi sensasi nyeri). Tujuan penelitian adalah Untuk mengetahui pengaruh Al-Hijamah terhadap perubahan kadar leukosit. Jenis penelitian ini bersifat eksperimental uji klinis tanpa pembanding (Pre and Post test without control group design). Penelitian ini di lakukan di Klinik Bekam Ibnu Sina Palembang. Pemeriksaan darah di lakukan di Balai Besar Laboratorium Kesehatan (BBLK) daerah Sumatera Selatan. Waktu penelitian selama 14 hari. Besar sampel sebanyak 30 orang. Data karakteristik sampel dan hasil pengukuran dinilai homogenitas mengunakan uji Shafiro Wilk. Analisis deskripsi untuk mengetahui nilai rerata dan standar deviasi. Terjadi peningkatan yang signifikan nilai rerata leukosit. Al-Hijamah berpengaruh terhadap peningkatan kadar leukosit.
\end{abstract}

Kata kunci : Al-Hijamah, Leukosit 


\section{PENDAHULUAN}

Tubuh manusia memiliki sistem kekebalan tubuh untuk melawan agen infeksius dan toksin. Sistem kekebalan tubuh seluler diperantarai oleh leukosit (Guyton and Hall, 2012). Leukosit mampu keluar dari pembuluh darah menuju jaringan dalam menjalankan fungsinya. Fruktuasi leukosit dalam jumlah besar pada setiap individu terjadi pada kondisi stress, aktivitas fisiologi yang tinggi, gizi dan umur. Jumlah leukosit yang menyimpang dari keadaan normal mempunyai arti klinik penting untuk evaluasi proses penyakit (Saputri et al, 2011).

Al-Hijamah berasal dari istilah bahasa arab yang berarti mengurangi ukuran yakni mengembalikan tubuh pada kondisi alamiah dengan cara melepas darah kotor (Sharaf, 2012). Al-Hijamah bagi umat islam memiliki keutamaan karena merupakan sunnah Nabi Muhammad SAW seperti disebutkan dalam hadits " Dari Anas bin Malik dia berkata, Rasulullah SAW " Sesungguhnya pengobatan paling ideal yang kalian pergunakan adalah Al-Hijamah dan qusthul bahri" (HR.Takhrij Ahmad, Al-Bukhori dan Muslim) (Ar-Rayis, 2018). Al-Hijamah adalah pengobatan mengunakan sarana gelas atau tabung kaca yang prosesnya diawali dengan melakukan pengkopan (membuat tekanan negatif dalam gelang, tabung) sehingga menimbulkan bendungan lokal pada permukaan kulit, dengan tujuan agar sirkulasi $Q i$ dan Xue meningkat, menimbulkan efek analgetik, anti radang, mengeluarkan racun serta sebagai anti oksidan (Hennawy, 2004).

Al-Hijamah bekerja dengan cara merangsang dan mengaktifkan sistem kekebalan tubuh, pengeluaran enkefalin, pelepasan neurotransmitter, penyempitsn dan pelebaran pembuluh darah dan the gates control theory pada system saraf pusat (yang berfungsi mengurangi sensasi nyeri (Mahdavi, 2013). Proses inflamasi, penyayatan dan blood letting yang dilakukan pada Al-Hijamah dianggap sebagai expose stressor yang akan membahayakan jaringan tubuh sehingga akan menyebabkan terjadinya stres fisik (Kadir, 2010). Respons umum/ general adaptation sydrome terhadap stres fisik adalah memacu serangkaian reaksi reaksi dari sistem hypothalamus-pituitary-cortex adrenal (HPA) yang menghasilkan adrenocorticotropin hormone dan kortisol (kortisteroid) dan sistem
Hypothalamus-pituitary- sympathetic-adrenomedullary (SAM) yang mengaktivasi sistem saraf simpatik untuk mensekresi epinefrin, norepinefrin dan dopamine (Nugroho, 2011) Hormon tersebut akan mengaktivasi leukosit dan sistem komplementer dan sumsum tulang (Kadir, 2010; Nugroho, 2011). Tujuan penelitian adalah untuk mengetahui pengaruh Al-Hijamah terhadap perubahan kadar leukosit.

\section{METODE}

Jenis penelitian ini bersifat eksperimental uji klinis tanpa pembanding (pre and post test without control group design). Penelitian ini di lakukan di klinik bekam Ibnu Sina Palembang. Pemeriksaan darah di lakukan di Balai Besar Laboratorium Kesehatan (BBLK) daerah Sumatera Selatan. Waktu penelitian selama 14 hari. Populasi dalam penelitian ini adalah seluruh klien laki-laki dewasa yang melakukan terapi bekam di Klinik Bekam Ibnu Sina Palembang. Sampel dalam penelitian ini adalah sebagian klien laki-laki dewasa yang memenuhi kriteria inklusi dan ekslusi. Besar sampel sebanyak 30 orang. Setiap sampel yang memenuhi kriteria inklusi dan eklusi diambil secara radomisasi/ acak sampai jumlah sampel yang diinginkan. Kepada semua sampel dijelaskan tujuan, prosedur, manfaat serta resiko sebagai sampel dalam penelitian ini. Setelah mendapat persetujuan sampel kemudian menanda tangani informed concent menjadi responden. Variabel penelitian adalah: variabel bebas (independen) yaitu Al-Hijamah dan variabel terikat (dependen) adalah kadar leukosit. Perlakuan terhadap subjek penelitian, untuk meminimalisasi faktor perancu (confounding factors) maka setiap subjek penelitian diminta untuk menanda tangani surat bersedia untuk tidak berolahraga dan tidak mengkonsumsi suplemen dan minuman anti oksidan sebelum diambil darah pretesnya dan setelah perlakuan sampai sebelum diambil darah postes.

Terapi Al-Hijamah dilaksanakan oleh terapis klinik Bekam Ibnu Sina yang terlatih dan telah tersertifikasi sebagai terapi bekam dari Perkumpulan Bekam Indonesia (PBI) Peralatan dan bahan yang digunakan dalam penelitian ini adalah mengunakan peralatan bekam SOP PBI antara lain; tabung kop/ gelas cupping dan handpump (pompa bekam), lancing device, lancet (jarum steril), nampan/ 
baskom stainless, mangkok oval/ nierbekken, mangkok kecil steinless pisau bedah, scapel (gagang pisau bedah), gunting, apron, penjepit kasa (klem pean). kain duk, sarung tangan, masker wajah, mangkok/ cawan, kasa steril, kapas, tempat sampah, meja, kursi dan bed periksa. Jika memungkinkan diusahakan memiliki tabung oksigen untuk mengantisipasi apabila terjadi pingsan. Bahan yang digunakan adalah: betadine (iodine), alkohol 70\%, larutan $\mathrm{H}_{2} \mathrm{O}_{2}$, minyak zaitun dan minyak habatussauda dan Sterilisator (Sarkosih, 2012; Fatahillah, 2019). pemeriksaan darah vena (lancet darah, jarum, semprit dan botol, (peralatan dan bahan untuk pmeriksaan leukosit secara manual) hemositometer, kaca objek dan kaca penutup, mikroskop. Peralatan dan pemeriksaan leukosit mengunakan automatic hematology analyzer sismex $K X 2$.

Tidak ada persiapan khusus dalam melakukan terapi Al-Hijamah. Klien disarankan makan terlebih dahulu 2 jam sebelum dilakukan Al-Hijamah untuk menghindari pingsan. Dilakukan pemeriksaan umum meliputi: tekanan darah, nadi, temperatur dan pernapasan. Menentukan titik Al-Hijamah berdasarkan titik sunah. Melakukan pemijatan/ urut seluruh tubuh dengan minyak habbatussauda atau minyak zaitun selama 5-10 menit. Vakum/ hisap dengan gelas/ cup pada kulit di titik-titik Al-Hijamah, dipompa 3-5 kali. Biarkan selama 2-3 menit. Melepaskan gelas cupping, desinfeksi kulit mengunakan betadine/ minyak zaitun, melakukan penusukan dengan lancet, 15-20 tusukan, lalu hisap/ vakum dengan cupping set dan handpump. Dapat diulangi sebanyak 2-3 kali (disesuaikan dengan ketahanan tubuh pasien) dan dibiarkan selama 5- 10 menit. Membuka gelas cupping dan membersihkan darah mengunakan kasa steril. Setelah selesai daerah bekam/ Al-Hijamah diberikan antiseptik, untuk pencegahan infeksi.

Pemeriksaan darah vena (lancet darah, jarum, semprit dan botol, (peralatan dan bahan untuk pmeriksaan leukosit secara manual) hemositometer, kaca objek dan kaca penutup, mikroskop. Peralatan dan pemeriksaan leukosit mengunakan automatic hematology analyzer sismex $K X 2$.

\section{HASIL}

Hasil yang diperoleh merupakan data sebelum dan sesudah dilakukan Al-Hijamah. Data yang diperoleh dalam penelitian ini kemudian dianalisis secara statistik mengunakan program SPSS versi 20, yang meliputi uji homogenitas sampel mengunakan uji Shafiro Wilk, analisa deskripsi untuk mengetahui nilai rerata dan standar deviasi. Data yang dihasilkan terdistribusi secara normal, limposit dan eosinofit tidak terdistribusi secara normal maka dilanjutkan mengunakan uji Wilcoxon

\section{Tabel 1. Karakteristik Umur Responden}

\begin{tabular}{lcc}
\hline Umur (Tahun) & $\mathbf{n}$ & $\mathbf{\%}$ \\
\hline $25-40$ & 18 & 60 \\
$41-55$ & 12 & 40 \\
\hline Total & $\mathbf{3 0}$ & $\mathbf{1 0 0}$ \\
\hline
\end{tabular}

Dari Table 1 menunjukkan bahwa dari 30 sampel penelitian didapatkan kisaran umur responden terbanyak adalah 25-40 tahun yaitu sebanyak 18 orang $(60 \%)$.

Tabel 2. Nilai Rerata Leukosit

\begin{tabular}{lllll}
\hline Variabel & \multicolumn{2}{c}{ Rerata \pm SD } & \multicolumn{2}{c}{ Min-Maks } \\
\cline { 2 - 5 } & pre & post & pre & post \\
\hline Leukosit & $6.75 \pm$ & $8.22 \pm$ & $4.80-$ & $5.50-$ \\
$(\mathrm{Sel} / \mu \mathrm{L}$ & 1.27 & 1.55 & 10.60 & 13.20 \\
\hline
\end{tabular}

Dari Tabel 2 menunjukkan nilai Minimum dan maksimum pre sebesar 4.80-10.60 dan nilai post sebesar 5.50-13.20

Hasil uji normalitas terhadap jumlah leukosit sebelum Al-Hijamah terdistribusi secara normal ( $\mathrm{p}=0.096)$ maka dilanjutkan dengan uji statistik Paired t-test

Tabel 3. Perbedaan Rerata Leukosit

\begin{tabular}{|c|c|c|}
\hline Variabel & Rerata \pm SD & $\begin{array}{c}p \\
\text { value }\end{array}$ \\
\hline $\begin{array}{l}\text { Leukosit pre } \\
(\mathrm{Sel} / \mu \mathrm{L})\end{array}$ & $6.75 \pm 1.27$ & 0.000 \\
\hline $\begin{array}{l}\text { Leukosit post } \\
(\mathrm{Sel} / \mu \mathrm{L})\end{array}$ & $8.22 \pm 1.51$ & \\
\hline
\end{tabular}

Dari Tabel 3 menunjukkan bahwa nilai rerata leukosit pre adalah $6.75 \pm 1.27$ sedangkan nilai rerata leukosit post adalah $8.22 \pm 1.51$ dengan selisih rerata sebesar 1.47. Hasil uji statistik mengunakan uji Paired T-test didapatkan nilai $p=0.000$ dengan nilai $\alpha=0.05 \quad(p<\alpha)$. Ho ditolak, hal ini menunjukkan ada perbedaan yang bermakna nilai rerata leukosit sebelum dan setelah pengobatan Al-Hijamah. 


\section{PEMBAHASAN}

\section{Pengaruh Al-Hijamah terhadap Perubahan Kadar Leukosit}

Dari hasil uji statistik terhadap kadar leukosit didapati nilai rerata jumlah leukosit sesudah Al-Hijamah mengalami peningkatan yang bermakna. Hasil penelitian ini sejalan dengan penelitian Khalil (2013) bahwa terjadi peningkatan yang bermakna terhadap jumlah leukosit setelah 1 minggu dilakukan Al-Hijamah. Penelitian Mahdavi et al (2013) menyatakan bahwa terjadi peningkatan jumlah leukosit setelah 2 minggu dilakukan Al-Hijamah meskipun tidak signifikan.

Menurut Sharaf (2012) Al-Hijamah berperan mengatur sirkulasi darah di dalam tubuh melalui zat Nitrit Oksida (NO) yang berperan mendilatasi pembuluh darah. Al-Hijamah berperan mengurangi darah dan cairan yang menyertai proses peradangan dengan cara mengeluarkan cairan-cairan ini dari celah-celah antar sel (Sharaf, 2012). Pengobatan Al-Hijamah merupakan metode pengeluaran darah statis atau darah kotor, yang dapat membahayakan tubuh jika tidak dikeluarkan (sharaf, 2012). Efek Al-Hijamah tidak terbatas pada pembersihan darah mengendap (stagnant bood) dari kulit, namun juga menghilangkan zat-zat berbahaya yang mengendap di bawah kulit (Sharaf, 2012).

Menurut Hennawy (2004) jila dilakukan Al-Hijamah pada satu titik (poin) maka kulit (kutis), subkutis, fascia dan otot akan terjadi kerusakan pada sel mast. Akibat kerusakan ini akan dilepas beberapa zat seperti serotonin, slow reacting substance (SRS) dan zat-zat lain. Histamin bertanggung jawab pada perubahan awal yaitu menyebabkan vasodilatasi pada arteriol dan terjadinya peningkatan dilatasi kapiler dan arteriol serta false reacting. Dilatasi kapiler juga terjadi di tempat yang jauh dari tempat Al-Hijamah, hal ini menyebabkan terjadinya perbaikan micro circulation peredaran darah. Reaksi pembengkakan/ Inflamasi pada saat pengkopan merupakan reaksi cepat terhadap kerusakan jaringan. Inflamasi sangat berguna bagi pertahanan tubuh sebab reaksi inlaamasi tersebut dapat mencegah kerusakan ke jaringan sekitarnya dan mempercepat proses penyembuhan (Widada, 2011). Respon inflamasi lokal terdiri dari: merah (rubor), panas (kalor), bengkak (tumor), nyeri (dolor) dan gangguan fungsi (fungsi laesa)

Leukosit mempunyai peranan dalam sistem pertahanan tubuh seluler dan hormonal. Lekosit berperan sebagai penahan invasi patogen melalui proses fagositosis, mengidentifikasi dan menghancurkan sel-sel kanker dan sebagai pembersih yang membersihkan debris yang berasal dari sel-sel mati, yang penting dalam penyembuhan luka dan perbaikan jaringan. Untuk melaksanakan fungsinya leukosit terutama mengunakan strategi "cari dan serang" yaitu pergi ke tempat invasi atau jaringan rusak. Alasan utama leukosit terdapat di dalam darah adalah agar cepat diangkut dari tempat penyimpanannya dimanapun diperlukan (Sherwood L, 2004; Harahap, 2008). Jumlah leukosit dalam sirkulasi darah sangat cepat berubah. Nilai absolut maupun relatif dapat berubah oleh stimulasi selama beberapa menit atau jam (Harahap, 2008).

Peningkatan kadar leukosit setelah Al-Hijamah diduga karena banyaknya leukosit yang mengikuti (masuk) ke dalam dinding pembuluh darah (endothelium) dengan car merembes (diapedesis) ke dalam sirkulasi darah disebabkan karena leukosit teraktivasi oleh reaksi inflamasi dan expossure stressor. Hal ini sejalan dengan pendapat peneliti lain bahwa jumlah leukosit yang meningkat merupakan protektif terhadap stres fisik akibat dilakukannya Al-Hijamah. Peningkatan ini disebabkan karena epinephrine dan norepinephrine yang dilepas ke dalam plasma menyebabkan marked pengaruh fisiologi pada heart rate dan vasomotor tone yang akhirnya membentuk pola aliran darah melalui jaringan limpa dan sirkulasi leukosit ${ }^{(9)}$.

Peningkatan jumlah leukosit setelah Al-Hijamah adalah dalam rentan normal, yang bertujuan untuk mengembalikan homeostatis sistem kekebalan tubuh (Bilal, 2011). Dalam kondisi Leukosit yang menurun yang disebabkan karena aktifitas fisik yang berlebihan, kurang istirahat, makan makanan yang mengandung pengawet dan pemanis buatan, terpapar radikal bebas yang berasal dari asap kendaraan dan pabrik yang terus menerus maka direkomendasikan untuk melakukan pengobatan Al-Hijamah. Menurut penelitian (Widada, 2011) pengobatan Al-Hijamah yang dilakukan secara teratur diduga kuat dapat menstimulasi kerja 
kekebalan seluler sehingga daya tahan tubuh meningkap yang pada akhirnya meningkatkan kesehatan dan kebugaran.

\section{SIMPULAN}

Berdasarkan hasil analisis pembahasan, maka dapat disimpulkan bahwa, Terjadi peningkatan yang bermakna terhadap kadar Leukosit setelah terapi Al-Hijamah $(\mathrm{p}<0,05)$ dengan kenaikan sebesar $1.13 \%$. Hasil penelitian ini dapat menjadi landasan ilmiah dan bahan informasi kepada masyarakat tentang manfaat Al-Hijamah yang dapat dipergunakan pada penderita penyakit akibat virus/ mikro organisme yang tidak patogen. Penelitian ini perlu dilanjutkan karena baru mengungkapkan pengaruh Al-Hijamah terhadap kadar leukosit, belum mampu mengambarkan sistem kekebalan tubuh secara lengkap, maka disarankan penelitian lebih lanjut pada tingkat biomolekuler terhadap parameter kadar sitokin yang berperan pada reaksi inflamasi seperti TNF- $\alpha$, Interleukin 1,3,6 dan Interferon, sel T $C D 4^{+}$Interleukin-2, dan Interleukin-10.

\section{DAFTAR PUSTAKA}

Ahmadia, A., Farhadia, K. and Schwebelb, D.C. 2009. The Effectiveness of Wet cupping for Nonspesific Low Back Pain in Iran: A Randamized controlled trial. BMC Complementary Therapies and Alternative Medicine 17: 9-15.

Ar-Rayis, A., Khalifah, MS. 2018. Panduan bekam Bergambar. Seni Bekam Syar'I Untuk Terapi Penyakit Masa Kini. Zam za. Jakarta.

Bilal, Rafeeq, Ahmed and Afroz. 2011. Parsial Evaluation of Tecnique Used in Cupping Therapy. Journal of Basic and Applied Sccience 7 (1): 65-8.

Effendi. 2003. Peranan leukosit Sebagai Anti Inflamasi Alergik dalam Tubuh. Artikel Fakultas Kedokteran Universitas Sumatera Utara. Medan.

El Sayed, Mahmoud and Nabo. 2013. Methods of Wet Cupping Therapy (Al-Hijamah): In Light of Modern Medicine and
Prophertic Medicine. Altern Integ Med 2 (3): 1-16.

Fatahillah A., Suhardi K., Akbar Z., 2019. Panduan Pengajaran Bekam Perkumpulan Bekam Indonesia. Cetakan ke-5. Bidang Diklat dan Litbang PBI.

Guyton and Hall. 2012. Buku Ajar Fisiologi kedokteran (Edisi ke-11). EGC. Jakarta.

Handayani dan Wiwik. 2008. Asuhan Keperawatan pada Klien dengan Gangguan Sistem Imunologi. Salemba Medika. Jakarta.

Harahap, N.S. 2008. Pengaruh Aktifitas Fisik Maksimal terhadap Jumlah Leukosit dan Hitung Jenis leukosit pada Mencit (Mus musculus L) Jantan. Tesis Universitas Sumatera Utara. Medan.

Hennawy. 2004. Cupping Therapy and Infertility. Available at (http://www.obgyn. net, diakses 10 Nopember 2016).

Irianri dan Ardinata. 2008. Pengaruh Aktifitas Fisik Sedang Terhadap Hitung Leukosit dan Hitung jenis Leukosit pada Orang Tidak Terlatih. Jurnal Majalah Kedokteran Nusantara 41 (4): 259-67.

Jasmika. 2013. The Art of Human Body System Immune (http://www.goegle com, diakses 22 Oktober 2016).

Kadir, A. 2010. Perubahan Hormon Terhadap Stres. Jurnal kesehatan Universitas Wijaya Kusuma 2(1): 32-9.

Khalil, Al-qaoud and Shaqqour. 2013. Investigation of selected Immunocyto genetic Effects of Wet Cupping in Healthy Men. Journal Spatulla DD 3 (2): 51-7

Lawrence, Derek, A., Willoughby and W. Gilroy. et al. 2002. Anti-Inflammatory Lipid Mediators and Insight Into. The Resolution of Inflammation Nature Review 2: 21-7.

Mahdavi, Ghazanfari, Aghajani, Danyali and Naseri, et al. 2013. Evaluation of the effects of Traditional Cupping on the Biochemical, Hematological and 
Immunological Factors of Human Venous Blood. Journal Compendium of Essays on Alternative Therapy 7:68-88.

Nugroho, Pujo dan Nurcahyo. 2011. Fisiologi dan Patofisiologi Aksis HipotalamusHipofisis-Adrenal. Jurnal Anastesional Indonesia 3 (2) 132-143.

Saputri, Dyah, dan Abdulgani. 2011. Jumlah Total dan Differensial Leukosit mencit (Mus Musculus) pada Evaluasi In Vivo Anti Kanker Ekstrak Spons Laut (Aaotos Suberitoides). Artikel Fakultas MIPA. Institut Tehnologi Sepuluh Nopember, Surabaya.

Sarkosih. 2012. Identifikasi Keselamatan pasien Terapi Bekam di 4 (Empat) Wilayah DKI Jakarta. Tesis Fakultas Kesehatan Masyarakat, Universitas Indonesia.

Sherwood and Laurelee. 2001. Fisiologi Manusia dari Sel ke Sel. EGC. Jakarta.

Sharaf, A.R. 2012. Penyakit dan Terapi bekamnya; Dasar-dasar Ilmiah Terapi Bekam. Terjemahan oleh: Murtadlo, Saptorini (editor) Sukaeta. Thibbia.

Widada. 2011. Pengaruh Bekam terhadap Peningkatan Sistem Kekebalan: Sel Limfosit T Sitotoksik. Jurnal Forikes 2 (4): 219-223. 